\begin{tabular}{llll} 
Jurnal Maksipreneur: & Vol. 11 No. $1 \quad$ Desember 2021 & hal. $69-89$ \\
Manajemen, Koperasi, dan Entrepreneurship & & \\
\hline
\end{tabular}

\title{
Pengaruh Non-Performing Loan (NPL) dan Loan to Deposit Ratio (LDR) terhadap Return on Asset (ROA) dengan Net Interest Margin (NIM) sebagai Variabel Mediasi pada Bank BUMN yang Terdaftar di BEI
}

\author{
Suci Susilawati \\ Nafisah Nurulrahmatiah \\ Manajemen, Sekolah Tinggi Ilmu Ekonomi (STIE) Bima, Indonesia \\ Korespondensi penulis: sucisusilawati777@gmail.com
}

\begin{abstract}
The financial performance of a bank can be measured through ROA. Bank Indonesia as a supervisory and supervisory institution prioritizes greater profitability, namely the Return on Asset (ROA) of a bank, so banks need to know what factors can affect the ROA of a bank. This study was conducted to analyze the effect of Non Performing Loans (NPL) and Loan to Deposit Ratio (LDR) on Return on Assets (ROA) with Net Interest Margin (NIM) as a mediating variable. The sample of this research consists of Bank Mandiri, Bank BNI, Bank BRI, and Bank BTN for the period 2015-2019. The research methods used include descriptive statistical analysis, outer model analysis, and inner model analysis. The results of this study indicate that NPL does not affect NIM, while LDR has a significant effect on NIM. Furthermore, NPL has a significant effect on ROA, while LDR does not affect ROA. This study also proves that NIM has a significant effect on ROA, but NIM does not mediate the effect of NPL on ROA, and NIM can mediate the effect of LDR on ROA.
\end{abstract}

Keywords: Bank; Loan to Deposit Ratio (LDR); Net Interest Margin (NIM); NonPerforming Loan (NPL); Return on Asset (ROA).

\begin{abstract}
Abstrak. Kinerja keuangan bank dapat diukur melalui ROA. Bank Indonesia sebagai lembaga pembina dan pengawas industri perbankan lebih mengedepankan besarnya profitabilitas, yaitu Return on Asset (ROA) bank, sehingga perbankan perlu mengetahui faktorfaktor apa saja yang dapat mempengaruhi ROA bank. Penelitian ini dilakukan untuk menganalisis pengaruh Non Performing Loan (NPL) dan Loan to Deposit Ratio (LDR) terhadap Return on Asset (ROA) dengan Net Interest Margin (NIM) sebagai variabel mediasi. Sampel penelitian ini terdiri atas Bank Mandiri, Bank BNI, Bank BRI, dan Bank BTN untuk periode tahun 2015-2019. Metode penelitian yang digunakan meliputi analisis statistik diskriptif, analisis outer model, dan analisis inner model. Hasil penelitian ini menunjukkan bahwa NPL tidak berpengaruh terhadap NIM, sedangkan LDR berpengaruh signi-
\end{abstract}


fikan terhadap NIM. Selanjutnya, NPL berpengaruh signifikan terhadap ROA, sedangkan LDR tidak berpengaruh terhadap ROA. Penelitian ini juga membuktikan bahwa NIM berpengaruh signifikan terhadap ROA, tetapi NIM tidak memediasi pengaruh NPL terhadapa ROA, serta NIM mampu memediasi pengaruh LDR terhadap ROA.

Kata kunci: Bank; Loan to Deposit Ratio (LDR); Net Interest Margin (NIM); Non-Performing Loan (NPL); Return on Asset (ROA).

\section{Article Info:}

Received: April 30, $2021 \quad$ Accepted: August 2, 2021

Available online: August 16, 2021

DOI: http://dx.doi.org/10.30588/jmp.v11i1.833

\section{LATAR BELAKANG}

Akivitas ekonomi yang semakin terintegrasi menyebabkan ekonomi berbagai negara di dunia saling terkait tanpa hambatan, sehingga jika terjadi krisis di suatu negara akan cepat berimbas ke negara-negara lain. Seperti krisis pada lembaga keuangan di tahun 2008 yang dialami oleh Amerika Serikat, dampak krisis tersebut berimbas ke negara-negara lainnya, khususnya negara yang memiliki hubungan ekonomi dengan Amerika Serikat (Septiani \& Lestari, 2016). Krisis lembaga keuangan di Amerika Serikat juga berdampak pada likuiditas lembaga keuangan, seperti perbankan di negara-negara lainnya terutama negara-negara yang menginvestasikan dananya pada instrumen lembaga keuangan besar di Amerika Serikat.

Bank sebagai lembaga intermediasi harus memiliki kinerja yang baik dengan cara memelihara dan meningkatkan kesehatan bank. Dengan demikian, bank dapat lebih mudah mendapatkan dan menjaga kepercayaan para nasabahnya (agent of trust) yang merupakan prinsip fundamental bank (Lalujan, Pelleng, \& Tumbel, 2016). Berdasarkan Peraturan Bank Indonesia nomor 13/1/PBI/2011 tentang Penilaian Kesehatan Bank Umum (Otoritas Jasa Keuangan, 2021a), bank diwajibkan untuk selalu memelihara dan meningkatkan tingkat kesehatan bank. Penelitian terhadap tingkat kesehatan bank dilakukan untuk mengetahui kinerja bank menggunakan laporan keuangan sebagai indikator yang mendasari penilaian kinerja keuangan bank (Soetjiati \& Mais, 2019). Perbankan menggunakan kinerja keuangan sebagai tolok ukur tingkat keberhasilan untuk menghasilkan laba bersih yang optimal, sehingga bank mampu menghasilkan pertumbuhan laba yang selalu meningkat setiap periode.

Kinerja keuangan perbankan dapat diukur menggunakan rasio profitabilitas. Menurut Bank Indonesia, rasio profitabilitas yang penting bagi bank adalah Return on Asset (ROA), sehingga penelitian ini menggunakan ROA sebagai tolak ukur penilaian kinerja keuangan bank. Bank Indonesia sebagai lembaga pembina dan pengawas perbankan di Indonesia lebih mengedepankan besarnya profitabilitas suatu bank yang diukur dengan aset yang dananya sebagian besar diperoleh melalui simpanan masyarakat (Astohar, Rahmadhani, \& Nurlita, 2019). Semakin tinggi nilai ROA, maka kinerja bank juga cenderung semakin baik, karena tingkat keuntungan yang dihasilkannya semakin besar. 
Dalam rasio profitabilitas selain Return on Asset (ROA), rasio yang juga sering digunakan adalah Net Interest Margin (NIM). NIM merupakan pendapatan utama bagi bank, serta sangat menentukan besarnya keuntungan atau laba bersih yang diperoleh (income) bank (Soetjiati \& Mais, 2019). Besaran nilai NIM dapat mempengaruhi laba atau ROA bank, sehingga hal itu dapat berdampak pada kinerja bank tersebut (Julaeha, 2015). Penelitian yang sama juga pernah dilakukan oleh Aminah, Suharsono, dan Ahmad (2016), Kassem dan Sakr (2018), Purwoko dan Sudiyanto (2013).

Selain menggunakan rasio profitabilitas, bank juga menggunakan rasio likuiditas untuk mengukur kinerja perbankan. Rasio likuiditas yang sering digunakan adalah Loan to Deposit Ratio (LDR). LDR merupakan rasio untuk mengukur kemampuan bank dalam memenuhi kewajiban jangka pendek (likuiditas) dengan membagi total kredit terhadap total dana pihak ketiga (Septiani \& Lestari, 2016). Apabila bank mampu menyalurkan kredit dengan efektif, maka LDR akan meningkat, artinya total kredit yang berhasil disalurkan lebih tinggi peningkatannya daripada peningkatan total dana pihak ketiga, sehingga keuntungan bank akan meningkat yang berarti ROA naik (Suciaty, Haming, \& Nur, 2019). Penelitian serupa juga pernah dilakukan oleh Ambarawati dan Abundanti (2018), Alamsyah (2018), serta Kunarsih, Andini, dan Suprijanto (2018).

Rasio berikutnya untuk mengukur kinerja bank adalah Non Performing Loan (NPL) yang merupakan bagian dari kualitas aktiva produktif. NPL merupakan rasio yang digunakan untuk mengetahui kemampuan bank dalam mengcover risiko pengembalian kredit oleh debitur. Meningkatnya nilai NPL akan berdampak buruk pada kualitas kredit yang diberikan, sehingga hal itu dapat menyebabkan kerugian bagi bank, sehingga ROA akan menurun, sebaliknya apabila tingkat NPL rendah, maka laba atau ROA bank akan meningkat (Rusnaini, Hamirul, \& Ariyanto M., 2019). Penelitian ini juga pernah dilakukan oleh Ambarawati \& Abundanti (2018), Putri, Wiagustini, \& Abundanti (2018), serta Choerudin, Yuniatun, \& Kusdiasmo (2016).

Bank yang digunakan dalam penelitian ini adalah bank BUMN (Badan Usaha Milik Negara) yang terdaftar di Bursa Efek Indonesia (BEI) untuk periode tahun 2015-2019. Bank BUMN terdiri atas PT Bank Mandiri, Tbk. (BMRI), PT Bank Negara Indonesia, Tbk. (BBNI), PT Bank Rakyat Indonesia, Tbk. (BBRI), dan PT Bank Tabungan Negara, Tbk. (BBTN). Awal tahun 2020 merupakan saat munculnya wabah Covid 19 yang terjadi hampir di seluruh belahan dunia tidak terkecuali di Indonesia. Akibat wabah global ini, hampir seluruh sektor terdampak, tidak hanya kesehatan. Sektor ekonomi pun mengalami tekanan serius akibat pandemi global Covid-19. Pembatasan aktivitas masyarakat berpengaruh besar terhadap aktivitas bisnis yang berimbas pada perekonomian secara keseluruhan. Kondisi ini berdampak pula pada dunia perbankan di Indonesia. Keadaan ekonomi yang sulit mengakibatkan kenaikan tingkat kredit bermasalah pada bank-bank terutama bank BUMN. Program restrukturisasi kredit bagi debitur terdampak Covid-19, seperti penurunan suku bunga dan penundaan pembayaran angsuran pokok yang dilakukan saat pandemi Covid-19 menyebabkan penurunan laba bank-bank BUMN. Data pertumbuhan laba pada periode tahun 2015-2019, bank BUMN mengalami pertumbuhan laba yang fluktuatif. Tabel 1 menggambarkan kinerja keuangan bank-bank BUMN pada periode tersebut. 
Tabel 1 menunjukkan bahwa laba bersih bank BUMN selama periode lima tahun, yaitu tahun 2015-2019 mengalami pertumbuhan yang fluktuatif. Bank Mandiri mencatat laba bersih yang menurun pada tahun 2016 sebesar Rp13,807 triliun dari tahun sebelumnya Rp20,335 triliun, kemudian terus meningkat menjadi sebesar Rp27,482 triliun pada tahun 2019. Dari segi pendapatan bunga bersih, Bank Mandiri mengalami pertumbuhan yang signifikan di tahun 2019 mencapai Rp 61,248 triliun. Selanjutnya, bank BNI juga mengalami pertumbuhan yang signifikan dari segi laba bersih mencapai Rp15,385 triliun yang berarti lebih besar dari tahun-tahun sebelumnya. Hal yang sama terjadi pada segi pendapatan bunga bersih yang terus meningkat mencapai Rp36,602 triliun pada tahun 2019.

Bank BRI mencatat laba bersih yang terus meningkat dari tahun 2015 hingga 2019 mencapai Rp34,414 triliun. Demikian pula dari segi pendapatan bunga bersih yang meningkat tajam hingga mencapai Rp81,707 trilliun pada tahun 2019. Di sisi lain, pertumbuhan laba bersih pada Bank BTN meningkat pada tahun 2017 sebesar Rp3,027 triliun dibandingkan tahun sebelumnya sebesar Rp2,619 triliun. Selanjutnya, laba Bank BTN terus menurun hingga mencapai Rp0,209 triliun atau Rp209 miliar pada tahun 2019. Sementara itu, pendapatan bunga bersih terus meningkat tipis hingga tahun 2018 mencapai Rp10,089 triliun, tetapi menurun kembali menjadi Rp8,962 triliun pada tahun 2019. Dari uraian tersebut, tujuan penelitian ini adalah untuk mengetahui pengaruh Non Performing Loan (NPL) dan Loan to Deposit Ratio (LDR) terhadap Return on Asset (ROA) melalui Net Interest Margin (NIM) pada bank BUMN yang terdaftar di Bursa Efek Indonesia (BEI) tahun 2015-2019.

Tabel 1. Laba Bersih dan Pendapatan Bunga Bersih Bank BUMN Tahun 2015-2019

\begin{tabular}{|c|c|c|c|}
\hline Bank BUMN & Tahun & $\begin{array}{l}\text { Laba Bersih } \\
\text { (triliun) }\end{array}$ & $\begin{array}{c}\text { Pendapatan Bunga Bersih } \\
\text { (triliun) }\end{array}$ \\
\hline \multirow[t]{5}{*}{ Mandiri } & 2015 & $\mathrm{Rp} 20,335$ & $\operatorname{Rp} 48,500$ \\
\hline & 2016 & $\operatorname{Rp} 13,807$ & $\operatorname{Rp} 54,477$ \\
\hline & 2017 & $\operatorname{Rp} 20,640$ & $\operatorname{Rp} 54,453$ \\
\hline & 2018 & $\operatorname{Rp} 25,015$ & $\operatorname{Rp} 57,330$ \\
\hline & 2019 & $\mathrm{Rp} 27,482$ & $\operatorname{Rp} 61,248$ \\
\hline \multirow[t]{5}{*}{ BNI } & 2015 & Rp 9,067 & $\mathrm{Rp} 25,560$ \\
\hline & 2016 & $\operatorname{Rp} 11,339$ & $\operatorname{Rp} 29,995$ \\
\hline & 2017 & Rp 13,616 & $\operatorname{Rp} 31,938$ \\
\hline & 2018 & $\operatorname{Rp} 15,015$ & $\operatorname{Rp} 35,446$ \\
\hline & 2019 & $\mathrm{Rp} 15,385$ & $\operatorname{Rp} 36,602$ \\
\hline \multirow[t]{5}{*}{ BRI } & 2015 & Rp 25,398 & $\operatorname{Rp} 58,280$ \\
\hline & 2016 & $\mathrm{Rp} 26,234$ & $\mathrm{Rp} 65,439$ \\
\hline & 2017 & $\operatorname{Rp} 28,997$ & $\operatorname{Rp} 73,018$ \\
\hline & 2018 & $\operatorname{Rp} 32,351$ & $\operatorname{Rp} 77,665$ \\
\hline & 2019 & $\operatorname{Rp} 34,414$ & $\operatorname{Rp} 81,707$ \\
\hline \multirow[t]{5}{*}{ BTN } & 2015 & $\mathrm{Rp} 1,851$ & $\mathrm{Rp} 6,811$ \\
\hline & 2016 & $\operatorname{Rp} 2,619$ & $\operatorname{Rp} 8,164$ \\
\hline & 2017 & $\mathrm{Rp} 3,027$ & $\mathrm{Rp} 9,341$ \\
\hline & 2018 & $\mathrm{Rp} 2,808$ & $\mathrm{Rp} 10,089$ \\
\hline & 2019 & $\operatorname{Rp} 0,209$ & Rp 8,962 \\
\hline
\end{tabular}

Sumber: Bank BNI (2019), Bank BTN (2019), Bank BRI (2019), dan Bank Mandiri (2019). 


\section{KAJIAN TEORITIS}

\section{Analisis Rasio Keuangan}

Analisis rasio keuangan merupakan salah satu alat utama yang digunakan oleh setiap manajer keuangan untuk menganalisis keuangannya (Kasmir, 2012). Rasio keuangan dinilai sangat penting, karena berbagai pihak membutuhkannya untuk mengukur dan menilai seberapa besar kinerja keuangan atau posisi keuangan perusahaan tersebut. Pada umumnya, rasio keuangan yang digunakan untuk mengukur kinerja keuangan perbankan adalah rasio profitabilitas, rasio likuiditas, dan kualitas aktiva produktif (Parathon, 2013).

\section{Return on Asset (ROA)}

Return on Asset (ROA) merupakan salah satu macam rasio profitabilitas yang digunakan untuk mengukur kemampuan manajemen perbankan dalam memperoleh keuntungan (laba). Apabila ROA bank semakin tinggi, maka semakin tinggi pula profit atau laba yang dihasilkan, sehingga posisi bank dari segi aset yang dimiliki akan dinilai baik. Standar ROA yang ditetapkan oleh setiap bank berbeda-beda. Berdasarkan Surat Edaran (SE) nomor 13/24/DPNP tanggal 25 Oktober 2011 yang ditujukan kepada semua bank umum konvensional di Indonesia bahwa standar ROA bank yang ideal adalah 1,5\% (Otoritas Jasa Keuangan, 2011b). Penelitian ini menentukan ROA dengan formulasi dalam persamaan [1].

$$
\mathrm{ROA}=\frac{\text { Laba Sebelum Pajak }}{\text { Total Aktiva }} \times 100 \%
$$

\section{Net Interest Margin (NIM)}

Net Interest Margin (NIM) merupakan rasio untuk menghitung profitabilitas. Net interest margin (NIM) rasio untuk mengukur kemampuan manajemen bank dalam mengelola aktiva produktifnya guna menghasilkan pendapatan bunga bersih (Sudarmawanti \& Pramono, 2017). Apabila NIM yang diperoleh bank meningkat, maka pendapatan bunga yang berasal dari aktiva produktif yang dikelola bank juga ikut meningkat. Dengan demikian, hal itu akan meningkatkan laba bersih atau ROA bank tersebut (Astohar et al., 2019). Berdasarkan Peraturan Bank Indonesia, angka standar NIM yang ditetapkan adalah 6\%. Dalam penelitian ini, NIM dihitung mengunakan persamaan [2].

$$
\mathrm{NIM}=\frac{\text { Pendapatan Bunga Bersih }}{\text { Aktiva Produktif }} \times 100 \%
$$

\section{Non-Performing Loan (NPL)}

Non-Performing Loan (NPL) adalah salah satu alat ukur yang menjadi bagian dari rasio kualitas aktiva produktif. NPL merupakan rasio yang digunakan untuk mengukur kemampuan bank untuk mengelola kredit bermasalah yang disalurkannya. Semakin besar nilai NPL menunjukkan bahwa kualitas kredit bank semakin buruk. Hal itu menyebabkan semakin meningkatnya jumlah kredit bermasalah yang berdampak pada buruknya kondisi bank tersebut (Sudarmawanti \& Pramono, 2017). Menurut Peraturan Bank Indonesia no- 
mor 17/11/PBI/2015 standar NPL yang ditetapkan adalah 5\% (BPK, 2015). Artinya, jika nilai NPL lebih dari 5\%, maka bank tersebut dinilai tidak sehat. NPL dalam penelitian ini dihitung menggunakan formulasi persamaan [3].

$$
\mathrm{NPL}=\frac{\text { Kredit bermasalah }}{\text { Total kredit yang diberikan }} \times 100 \%
$$

\section{Loan to Deposit Ratio ( LDR)}

Rasio yang digunakan untuk menilai risiko likuiditas adalah Loan to Deposit Ratio (LDR). LDR merupakan rasio yang digunakan untuk mengetahui besarnya komposisi jumlah kredit yang diberikan dibandingkan dengan jumlah dana yang digunakan yang diperoleh dari masyarakat dan modal sendiri (Andrianto, Fatihuddin, \& Firmansyah, 2019). Dengan diterbitkannya Peraturan Bank Indonesia nomor 17/11/PBI/2015 tentang Perubahan atas Peraturan Bank Indonesia nomor 15/15/PBI/2013 bahwa mulai tanggal 3 Agustus 2015 semua penyebutan Loan to Deposit Ratio (LDR) dalam peraturan bank dibaca sebagai Loan to Funding Ratio (LFR). Besaran dan parameter yang digunakan dalam perhitungan LDR/LFR ditetapkan dalam Peratuan Bank Indonesia nomor 17/11/PBI/2015, batas bawah LDR/LFR target sebesar 78\% dan batas atas LDR/LFR sebesar 94\%. Perhitungan LDR dalam penelitian ini mengacu pada persamaan [4].

$$
\mathrm{NIM}=\frac{\text { Total } \text { kredit yang diberikan }}{\text { Total Dana Pihak Ketiga }} \times 100 \%
$$

\section{Pengaruh NPL terhadap NIM}

Rasio NPL menunjukkan tingkat kredit bermasalah yang dimiliki bank, apabila tingkat NPL yang dimiliki bank tinggi, maka kondisi itu akan menurunkan tingkat pendapatan bunga bank (Nugrahaning \& Wahyudi, 2016). Penelitian yang dilakukan oleh Syarif (2006), serta Rokhim dan Wulandary (2013) menunjukkan NPL memiliki pengaruh negatif terhadap NIM. Hal tersebut mengindikasikan bahwa peningkatan NPL dapat menurunkan pendapatan bunga bersih bank, sehingga penelitian ini mengajukan hipotesis kesatu (H1) sebagai berikut:

\section{$\mathrm{H}_{1}$ : Non-Performing Loan (NPL) berpengaruh signifikan terhadap Net Interest Mar- gin (NIM).}

\section{Pengaruh LDR terhadap NIM}

LDR menggambarkan jumlah kredit yang disalurkan oleh bank. Meningkatnya LDR menunjukkan peningkatan kredit yang dapat disalurkan oleh bank, sehingga peningkatan tersebut berpengaruh pada peningkatan NIM, karena semakin tingginya penerimaan pendapatan bunga yang berasal dari kredit yang tersalurkan. Penelitian yang dilakukan oleh Raharjo, Hakim, Manurung, dan Maulana (2014), serta Nugrahaning \& Wahyudi (2016) 
menyimpulkan bahwa LDR berpengaruh signifikan terhadap NIM. Artinya, peningkatan LDR akan berdampak pada peningkatan NIM, karena terjadi peningkatan pendapatan bunga bank yang diperoleh dari pinjaman yang disalurkan, sehingga hipotesis kedua $(\mathrm{H} 2)$ dalam penelitian ini diformulasikan sebagai berikut:

\section{$\mathrm{H}_{2}$ : Loan to Deposit Ratio (LDR) berpengaruh signifikan terhadap Net Interest Margin (NIM).}

\section{Pengaruh NPL terhadap ROA}

Tingginya tingkat NPL dapat memberikan masalah buruk bagi manajemen bank, karena tidak adanya pemulihan aset utama bank (Million, Matewos, \& Sujata, 2015), sehingga apabila NPL meningkat, maka Return on Asset (ROA) akan mengalami penurunan. Penelitian yang dilakukan oleh Ambarawati \& Abundanti (2018), Puspitasari (2014), serta Choerudin et al. (2016) menyimpulkan bahwa NPL berpengaruh signifikan terhadap ROA. Artinya, jika NPL meningkat, maka kondisi tersebut akan menyebabkan ROA bank menurun, sehingga hipotesis ketiga (H3) dalam penelitian ini dirumuskan sebagai berikut:

\section{$\mathrm{H}_{3}$ : Non-Performing Loan (NPL) berpengaruh signifikan terhadap Return on Asset (ROA).}

\section{Pengaruh LDR terhadap ROA}

LDR dapat mengindikasikan penyaluran dana pinjaman yang semakin besar. Apabila LDR meningkat, maka peningkatan tersebut dapat meningkatkan laba bersih bank, sehingga ROA semakin tinggi (Suciaty et al., 2019). Penelitian terdahulu yang dilakukan oleh Ambarawati dan Abundanti (2018) dan Kunarsih et al. (2018) menyimpulkan bahwa LDR berpengaruh signifikan terhadap ROA. Artinya, semakin tinggi LDR, maka kondisi tersebut dapat meningkatkan laba bersih, sehingga ROA bank meningkat. Dari uraian tersebut, hipotesis keempat $(\mathrm{H} 4)$ dalam penelitian ini dirumuskan sebagai berikut:

\section{$\mathrm{H}_{4}$ : Loan to Deposit Ratio (LDR) berpengaruh signifikan terhadap Return on Asset (ROA).}

\section{Pengaruh NIM terhadap ROA}

NIM menunjukkan pendapatan bunga bersih, yaitu semakin besar nilai NIM, maka pendapatan bunga atas aktiva produktif yang dikelola bank semakin meningkat, sehingga kemungkinan terjadinya kondisi bermasalah semakin kecil. Semakin besar nilai NIM suatu bank, maka semakin besar pula ROA bank tersebut. Penelitian terdahulu yang dilakukan oleh Purwoko dan Sudiyanto (2013) serta Bilal, Saeed, Gull, dan Akram (2013) menunjukkan bahwa NIM berpengaruh signifikan terhadap ROA. Artinya, semakin besar pendapatan bunga bersih (NIM), maka semakin besar laba yang diperoleh, sehingga penelitian ini memformulasikan hipotesis kelima (H5) sebagai berikut: 


\section{$\mathrm{H}_{5}$ : Net Interest Margin (NIM) berpengaruh signifikan terhadap Return on Asset (ROA).}

\section{Pengaruh NPL terhadap ROA melalui NIM}

Tingkat NPL bank yang terlalu tinggi dapat menurunkan kemungkinan bank memperoleh keuntungan atau laba. Penelitian terdahulu yang dilakukan oleh Ascarya dan Yumanita (2010), serta Wibisono dan Wahyuni (2017) menyatakan bahwa NIM dapat memediasi pengaruh NPL terhadap ROA. Artinya, NPL yang tinggi menyebabkan besarnya jumlah kredit bermasalah, sehingga pendapatan bunga menurun dan berpengaruh pula terhadap laba yang dihasilkan yang ikut menurun. Dari uraian tersebut, penelitian ini mengajukan hipotesis keenam (H6) dengan formulasi sebagai berikut:

\section{$\mathrm{H}_{6}$ : Non Performing Loan (NPL) berpengaruh signifikan terhadap Return on Asset (ROA) melalui Net Interest Margin (NIM).}

\section{Pengaruh LDR terhadap ROA melalui NIM}

Pengaruh LDR terhadap ROA yang dimediasi melalui NIM didukung oleh teori bank yaitu loan rate mark up, yaitu bank menetapkan markup yang lebih tinggi guna melindungi keuntungan atau laba yang ditargetkan. Hal itu menunjukkan bahwa likuiditas bank yang baik akan mampu meningkatkan ROA, apabila pendapatan bunga yang dimiliki bank (NIM) besar. Penelitian terdahulu yang dilakukan oleh Vodová (2013) menunjukkan bahwa NIM mampu memediasi pengaruh LDR terhadap ROA. Artinya, likuiditas bank yang baik dapat berdampak pada kenaikan ROA, apabila pendapatan bunga yang diperoleh bank besar. Berdasarkan informasi tersebut, penelitian ini mengajukan hipotesis ketujuh (H7) sebagai berikut:

\section{$\mathrm{H}_{7}$ : Loan to Deposit Ratio (LDR) berpengaruh signifikan terhadap Return on Asset (ROA) melalui Net Interest Margin (NIM).}

\section{Model Penelitian}

Berdasarkan landasan teori dan kajian empiris penelitian terdahulu, maka penelitian ini menggunakan model penelitian seperti yang ditunjukkan pada Gambar 1.

\section{METODE PENELITIAN}

\section{Jenis Penelitian}

Jenis penelitian ini adalah penelitian kuantitatif dengan menggunakan pendekatan asosiatif, yaitu penelitian yang bertujuan untuk mengetahui pengaruh dari dua variabel atau lebih. Penelitian ini dilakukan pada bank-bank BUMN yang terdaftar di BEI. Variabel yang digunakan dalam penelitian ini terdiri atas variabel bebas, yaitu NPL dan LDR, sedangkan variabel terikat adalah ROA, serta variabel mediasi adalah NIM. 


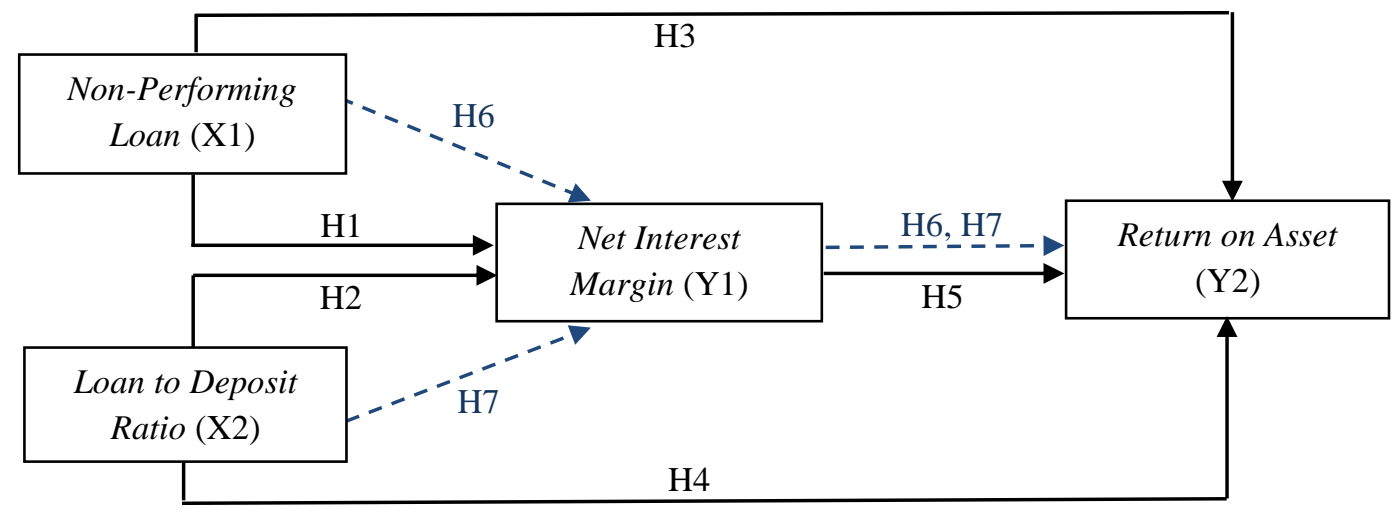

Keterangan:

$\begin{aligned} \longrightarrow & =\text { pengaruh langsung } \\ ------\rightarrow & =\text { pengaruh tidak langsung (melalui variabel mediasi). }\end{aligned}$

\section{Gambar 1. Model Penelitian}

\section{Populasi dan Sampel Penelitian}

Populasi penelitian ini adalah seluruh bank BUMN yang terdaftar di BEI. Bank BUMN yang terdaftar di BEI berjumlah empat Bank. Teknik sampling yang digunakan adalah pengambilan keseluruhan anggota populasi atau disebut sampling jenuh (Siyoto \& Sodik, 2015).

\section{Instrumen Penelitian}

Instrumen penelitian yang digunakan dalam penelitian ini adalah data laporan keuangan perusahaan yang terdiri atas neraca, laba rugi, dan arus kas periode tahun 20152019.

\section{Teknik Pengumpulan Data}

Pengumpulan data dalam penelitian ini menggunakan metode dokumentasi, yaitu data diperoleh dengan cara mengumpulkan dan mencatat secara langsung dari laporan keuangan tahunan yang dipublikasikan dari Bank Indonesia dalam Direktori Perbankan Indonesia (www.bi.co.id) dan laporan publikasi perhitungan rasio keuangan dari Otoritas Jasa Keuangan (www.ojk.go.id). Selain metode dokumentasi, data penelitian ini juga diperoleh melalui studi pustaka, seperti buku, publikasi penelitian terdahulu, dan artikel ilmiah yang dipublikasikan.

\section{Teknik Analisis Data}

Teknik analisis yang digunakan adalah analisis regresi partial (Partial Least Square atau PLS), yaitu teknik untuk mengetahui hubungan antarvariabel. Setiap hipotesis akan diuji dan dianalisis menggunakan software SmartPLS versi 3.0, yaitu versi student yang dijalankan dengan media komputer. Menurut Ghozali (2006), PLS merupakan alat analisis yang bersifat soft modeling yang analisisnya tidak memerlukan banyak asumsi dan ukuran sampel yang tidak terlalu besar (di bawah 100 unit sampel). Analisis PLS terdiri atas model 
pengukuran (measurement model) atau outer model dan model struktural (structural model) atau inner model.

\section{Analisis Statistik Diskriptif}

Menurut Ghozali (2006), statistik diskriptif merupakan analisis yang digunakan untuk memberikan gambaran atau diskripsi data yang dilihat dari nilai rata-rata (mean), varian, maksimum, minimum, sum, standar deviasi, range, kurtosis, dan skewness (kemencengan disribusi).

\section{Uji Model Pengukuran (Outer Model)}

Model pengukuran atau outer model digunakan untuk mengetahui bagaimana setiap blok indikator dapat berhubungan dengan variabel latennya (Sapti, 2010). Outer model digunakan untuk melakukan uji validity dan reliability instrument.

\section{Uji Validity}

a) Convergent Validity

Convergent validity digunakan untuk menguji validitas pada setiap variabel laten yang diukur melalui nilai Average Variance Extracted (AVE), apakah nilai satu konstruk dengan konstruk lain sama atau tidak. Nilai AVE yang disyaratkan lebih dari 0,5 (Aminah et al., 2016)

\section{b) Discriminant Validity}

Discriminant validity digunakan untuk menentukan apakah konstruk dalam model saling berkorelasi atau tidak, yaitu dengan membandingkan nilai loading factor dari konstruk tertentu dengan loading factor pada konstruk lain (Hussein, 2015).

\section{Uji Reliability}

Uji reliabilitas adalah analisis yang ditujukan untuk membuktikan seberapa akurat, konsistensi dan ketepatan suatu instrumen dalam mengukur konstruk. Pengukuran reliabilitas dilakukan dengan melihat nilai Cronbrach's alpha dan composite reliability dari blok indikator yang mengukur konstruk. Apabila nilai Cronbach's Alpha lebih besar atau sama dengan 0,7 dan composite reliability lebih besar atau sama dengan 0.7, maka konstruk tersebut dinyatakan reliable yang dapat diartikan memiliki komposit yang baik (Ghozali \& Latan, 2015).

\section{Uji Model Struktural atau Inner Model}

Inner model digunakan untuk mengetahui signifikansi hubungan antarkonstruk/ variabel dengan menggambarkan hubungan antarvariabel laten tersebut berdasarkan teori substantif penelitian (Hussein, 2015). Inner model terdiri atas uji goodness of fit dan path coefficient.

\section{Uji Goodness of Fit}

Goodness of fit diukur menggunakan R-square. Perubahan pada nilai $R$-square digunakan untuk menjelaskan pengaruh variabel laten eksogen tertentu terhadap variabel laten endogen, apakah mempunyai pengaruh yang substantif. Menurut Ghozali dan Latan (2015), 
nilai $R$-square adalah $0,75,0,50$, dan 0,25 yang dapat disimpulkan bahwa model penelitian dinyatakan kuat, moderat, dan lemah.

\section{Path Coefficient}

Uji path coefficient dilakukan untuk menguji hipotesis. Pengujian hipotesis dilakukan dengan melihat signifikansi pengaruh antarvariabel dengan melihat nilai p-values dan nilai signifikansi t-statistic melalui metode bootstrapping (Ghozali \& Latan, 2015). Uji t digunakan untuk menilai seberapa besar pengaruh langsung, pengaruh tidak langsung, dan pengaruh total. Dalam penelitian ini, jika nilai uji t lebih besar dari t-tabel, maka variabel tersebut berpengaruh signifikan dan seballiknya, sedangkan jika p-values kurang dari 5\% diartikan memiliki pengaruh dan sebaliknya (Hussein, 2015).

\section{HASIL DAN PEMBAHASAN}

\section{Analisis Statistik Diskriptif}

Hasil analisis statistik diskriptif pada penelitian ini ditunjukkan pada Tabel 2. Tabel 2 tersebut menyajikan hasil analisis statistik diskriptif variabel yang dianalisis, yaitu NonPerforming Loan (NPL) memiliki nilai minimum sebesar 44,000, dengan nilai maksimum sebesar 296.000, nilai rata-rata (mean) sebesar 117.800, nilai median sebesar 104.000 dan standard deviation sebesar 61.185. Selanjutnya, variabel Loan to Deposit Ratio (LDR) memiliki nilai minimum sebesar 8558,000; kemudian nilai maksimum sebesar 11350,000; nilai rata-rata (mean) sebesar 9353,700; nilai median sebesar 8957,000 dan standard deviation sebesar 816,587. Variabel Net Interest Margin (NIM) memiliki nilai minimum sebesar 332,000; nilai maksimum sebesar 827,000; nilai rata- rata (mean) sebesar 590,550; nilai median sebesar 563,000 dan simpangan baku (standard deviation) sebesar 128,525. Kemudian, variabel Return on Asset (ROA) memiliki nilai minimum sebesar 13,000; nilai maksimum sebesar 419,000; nilai rata-rata (mean) sebesar 263,750; nilai median sebesar 275,000 sedangkan nilai standard deviation sebesar 96,733.

Tabel 2. Hasil Analisis Diskriptif

\begin{tabular}{cccccccc}
\hline Variabel & No & Missing & Mean & Median & Min & Max & $\begin{array}{c}\text { Standard } \\
\text { Deviation }\end{array}$ \\
\hline NPL & 1 & 0 & 117,800 & 104,000 & 44,000 & 296,000 & 61,185 \\
\hline LDR & 2 & 0 & $9.353,700$ & $8.957,000$ & $8.558,000$ & $11.350,000$ & 816,587 \\
\hline NIM & 3 & 0 & 590,550 & 563,000 & 332,000 & 827,000 & 128,525 \\
\hline ROA & 4 & 0 & 263,750 & 275,000 & 13,000 & 419,000 & 96,733 \\
\hline
\end{tabular}

Sumber: Data sekunder diolah (2021).

\section{Analisis Outer Model}

Analisis Outer Model (pengukuran model) digunakan untuk menilai validitas dan reliabilitas model penelitian ini. Hasil analisis outer model ditunjukkan pada Gambar 2. 


\section{Convergent Validity}

Hasil pengujian validitas konvergen dapat diketahui pada Tabel 3 yang menunjukkan bahwa semua variabel memiliki nilai Cronbach's Alpha sebesar 1,000 atau lebih besar dari 0,7 dan nilai AVE sebesar 1,000 atau lebih besar dari 0,5, sehingga hasil tersebut mengindikasikan bahwa konstruk yang diukur mempunyai validitas yang baik (Hussein, 2015).

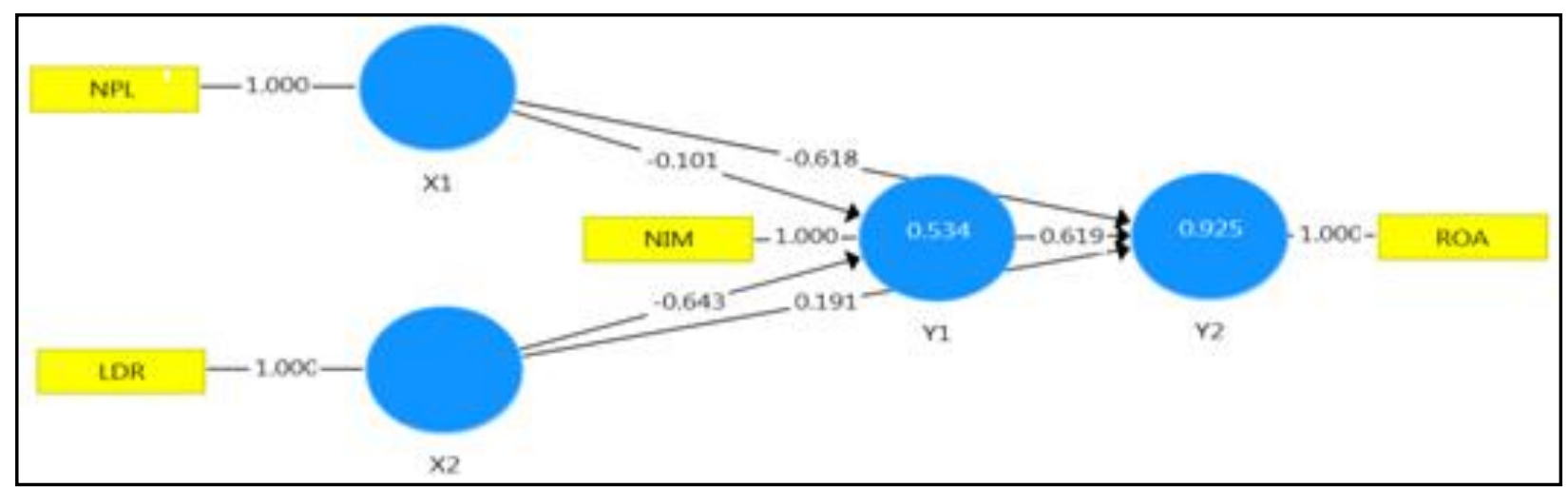

Sumber: Hasil output PLS sebelum bootstrapping (2021).

\section{Gambar 2. Diagram Pengukuran Model}

Tabel 3. Hasil Cronbach's Alpha dan AVE

\begin{tabular}{ccccc}
\hline & $\begin{array}{c}\text { Cronbach's } \\
\text { Alpha }\end{array}$ & rho_A & $\begin{array}{c}\text { Composite } \\
\text { Reliability }\end{array}$ & $\begin{array}{c}\text { Average Variance } \\
\text { Extracted (AVE) }\end{array}$ \\
\hline X1 & 1,000 & 1,000 & 1,000 & 1,000 \\
\hline X2 & 1,000 & 1,000 & 1,000 & 1,000 \\
\hline Y1 & 1,000 & 1,000 & 1,000 & 1,000 \\
\hdashline Y2 & 1,000 & 1,000 & 1,000 & 1,000 \\
\hline
\end{tabular}

Sumber: Data sekunder diolah (2021).

\section{Discriminant Validity}

Discriminant validity digunakan untuk mengetahui apakah indikator pada suatu konstruk mempunyai loading factor yang lebih besar dibandingkan dengan loading factor pada konstruk lainnya. Berdasarkan Tabel 4, nilai loading factor X1 sebesar 1,000 lebih besar dari loading factor pada konstruk lain. Begitu juga dengan nilai loading factor dari masingmasing variabel X2, Y1, dan Y2 yaitu 1,000 atau lebih besar dari loading factor konstruk lainnya, sehingga hasil tersebut mengindikasikan bahwa data tersebut memiliki nilai discriminant validity yang baik (Hussein, 2015). 
Tabel 4. Hasil Cross Loading

\begin{tabular}{ccccc}
\hline Variabel & X1 & X2 & Y1 & Y2 \\
\hline LDR & 0,846 & 1,000 & $-0,729$ & $-0,784$ \\
\hline NIM & $-0,645$ & $-0,729$ & 1,000 & 0,880 \\
\hline NPL & 1,000 & 0,846 & $-0,645$ & $-0,857$ \\
\hline ROA & $-0,857$ & $-0,784$ & 0,880 & 1,000 \\
\hline
\end{tabular}

Sumber: Data sekunder diolah (2021).

\section{Reliability}

Uji reliabilitas dapat diukur mennggunakan nilai composite reliability dan Cronbach's alpha. Berdasarkan Tabel 3, nilai composite reliability yang diperoleh sebesar 1,000 atau lebih besar dari 0,7 dan nilai Cronbach's Alpha sebesar 1,000 lebih besar dari 0,7, sehingga konstruk tersebut memiliki reliabilitas yang baik.

\section{Analisis Inner Model}

Analisis inner model digunakan untuk memperkirakan hubungan antara variabel laten (Ghozali \& Latan, 2015). Inner model diukur menggunakan nilai $\mathrm{R}^{2}$ (R-square) untuk mengetahui besarnya pengaruh antarvariabel. Selanjutnya, koefisien jalur (path coefficient) yang digunakan untuk menguji hipotesis guna mengetahui pengaruh signifikansi konstruk penelitian (Riduwan \& Kuncoro, 2012). Analisis inner model ditunjukkan pada Tabel 5.

Tabel 5. Hasil Perhitungan $\mathbf{R}^{2}$

\begin{tabular}{ccc}
\hline Variabel & R-square & Adjusted $R$-square \\
\hline Y1 & 0,534 & 0,479 \\
Y2 & 0,925 & 0,911 \\
\hline
\end{tabular}

Sumber: Data sekunder diolah (2021).

$R$-square digunakan untuk mengetahui tingkat pengaruh variabel laten eksogen terhadap variabel laten endogen. Nilai $R$-square yaitu $0,75,0,50$ dan 0,25 , sehingga hasil tersebut mengindikasikan bahwa model kuat, moderat, dan lemah (Ghozali \& Latan, 2015). Berdasarkan Tabel 5, pengukuran model dalam penelitian ini yang didasarkan pada analisis inner model adalah:

a. Besarnya pengaruh Non-Performing Loan (NPL) atau X1 dan Loan to Deposit Ratio (LDR) atau X2 terhadap Net Interest Margin (NIM) atau Y1 adalah 0,534 atau 53,4\%. Hasil tersebut menunjukkan bahwa model moderat.

b. Besarnya pengaruh Net Performing Loan (NPL) atau X1, Loan to Deposit Ratio (LDR) atau X2, dan Net Interest Margin (NIM) atau Y1 terhadap Return on Asset (ROA) atau Y2 sebesar 0,925 atau 92,5\%. Hasil tersebut mengindikasikan bahwa model kuat. 


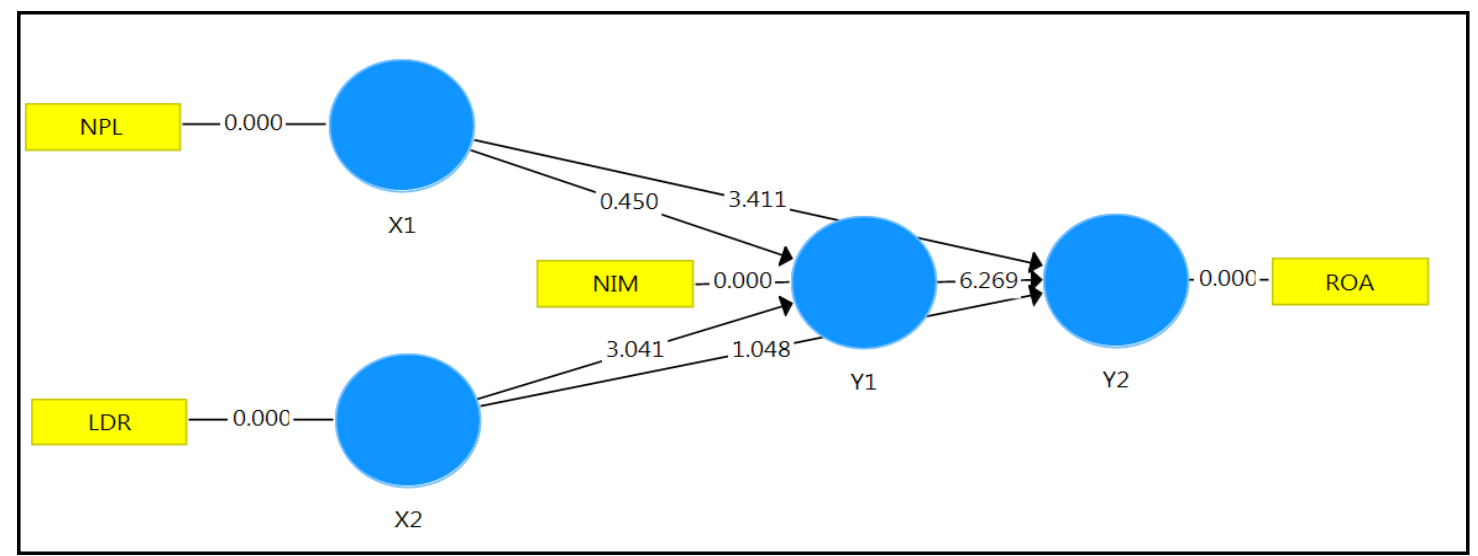

Sumber: Hasil output setelah bootstrapping (2021).

\section{Gambar 3. Diagram Model Struktural}

Gambar 3 menunjukkan diagram model struktural dalam penelitian ini setelah dilakukan bootstrapping. Boostrapping pada PLS dilakukan agar semua nilai yang dapat diolah dalam analisis PLS ini dapat menghasilkan nilai probabilitasnya, sehingga hasil tersebut dapat digunakan untuk mengembangkan uji hipotesis.

\section{Pengujian Hipotesis}

Uji hipotesis dalam penelitian ini dilakukan dengan menggunakan dua kriteria, yaitu $p$-values dan uji t ( $t$-statistics). Apabila nilai $p$-values kurang dari 5\%, maka variabel tersebut memiliki pengaruh signifikan. Di sisi lain, apabila uji t lebih besar dari t-tabel=1,96, maka variabel tersebut berpengaruh signifikan.

Tabel 6. Uji Hipotesis Pengaruh Langsung

\begin{tabular}{cccccc}
\hline Hipotesis & $\begin{array}{c}\text { Original } \\
\text { Sample }(\mathbf{O})\end{array}$ & $\begin{array}{c}\text { Sample } \\
\text { Mean }(\mathbf{M})\end{array}$ & $\begin{array}{c}\text { Standard Deviation } \\
\text { (STDEV) }\end{array}$ & $\begin{array}{c}\text { t-statistics } \\
\text { ([O/STDEV]) }\end{array}$ & p-values \\
\hline $\mathrm{X} 1 \rightarrow \mathrm{Y} 1$ & $-0,101$ & $-0,107$ & 0,225 & 0,450 & 0,653 \\
$\mathrm{X} 1 \rightarrow \mathrm{Y} 2$ & $-0,618$ & $-0,591$ & 0,181 & 3,411 & 0,001 \\
$\mathrm{X} 2 \rightarrow \mathrm{Y} 1$ & $-0,643$ & $-0,632$ & 0,211 & 3,041 & 0,002 \\
$\mathrm{X} 2 \rightarrow \mathrm{Y} 2$ & 0,191 & 0,173 & 0,182 & 1,048 & 0,295 \\
$\mathrm{Y} 1 \rightarrow \mathrm{Y} 2$ & 0,619 & 0,622 & 0,099 & 6,269 & 0,000 \\
\hline
\end{tabular}

Sumber: Data sekunder diolah (2021).

\section{Hasil Uji Pengaruh NPL (X1) terhadap NIM (Y1)}

Berdasarkan Tabel 6, nilai $p$-values variabel NPL (X1) menunjukkan nilai yang lebih besar dari 0,05, yaitu 0,653. Hasil tersebut menunjukkan bahwa NPL (X1) tidak memiliki pengaruh terhadap NIM (Y1), sedangkan uji t sebesar 0,450 lebih kecil dari 1,96 (nilai ttabel). Hasil uji t tersebut mengindikasikan bahwa tidak ada pengaruh NPL yang signifikan terhadap NIM, sehingga H1 ditolak. Hasil ini konsisten dengan Peraturan Bank Indonesia nomor 6/10/PBI/2004 tanggal 12 April 2004 tentang Sistem Penilaian Tingkat Kesehatan 
Bank Umum yang isinya bahwa apabila nilai NPL semakin tinggi atau lebih dari 5\% artinya kinerja bank terebut dinilai tidak sehat (BPK, 2004). Hasil penelitian ini sejalan dengan penelitian terdahulu oleh Nugrahaning dan Wahyudi (2016), Manurung dan Dezmercoledi (2013), serta Puspitasari (2014) yang menyimpulkan bahwa NPL tidak berpengaruh terhadap NIM. Hal tersebut dikarenakan rasio NPL bank BUMN yang terdaftar di BEI tahun 2015-2019 memiliki nilai yang rendah, sehingga hasil tersebut mengindikasikan tidak ada pengaruh pada pendapatan bunga bersih yang diperoleh bank BUMN tersebut.

\section{Hasil Uji Pengaruh LDR (X2) terhadap NIM (Y1)}

Berdasarkan Tabel 6, nilai dari p-values variabel LDR (X2) menunjukkan nilai kurang dari 0,05 yaitu 0,002. Hasil tersebut menunjukkan bahwa LDR berpengaruh signifikan terhadap NIM (Y1). Selanjutnya, nilai uji t sebesar 3,041 adalah lebih besar dari 1,96 atau nilai t-tabel. Uji t tersebut juga menunjukkan LDR berpengaruh signifikan terhadap NIM, sehingga H2 diterima. Berdasarkan hasil tersebut, LDR menunjukkan kemampuan bank BUMN yang dianalisis dalam menyalurkan kredit. Besarnya kredit yang berhasil disalurkan oleh bank-bank tersebut berpengaruh terhadap pendapatan bunga bank. Selanjutnya, kondisi tersebut juga akan berpengaruh terhadap peningkatan NIM. Hasil penelitian ini konsisten dengan penelitian yang dilakukan oleh Raharjo et al. (2014), Margaret dan Nurmayanti (2014), serta Nugrahaning dan Wahyudi (2016) yang menyimpulkan bahwa LDR berpengaruh signifikan terhadap NIM.

\section{Hasil Uji Pengaruh NPL (X1) terhadap ROA (Y2)}

Berdasarkan Tabel 6, nilai p-values variabel NPL (X1) menunjukkan nilai kurang dari 0,05 yaitu 0,001. Artinya, NPL berpengaruh secara signifikan terhadap ROA. Selanjutnya, nilai uji t sebesar 3,411 menunjukkan angka yang lebih besar dari 1,96 (nilai t-tabel) yang dapat diartikan bahwa NPL berpengaruh signifikan terhadap ROA. Dari hasil tersebut, maka H3 diterima. Non-Performig Loan (NPL) merupakan perbandingan antara kredit kurang lancar, diragukan, dan macet dengan total kredit yang telah diberikan oleh bank (Wulandari \& Purbawangsa, 2019). NPL yang rendah dapat meningkatkan nilai ROA, karena NPL yang rendah mengindikasikan semakin rendah risiko kredit yang ditanggung bank. Sebaliknya, apabila NPL semakin tinggi, maka probabilitas bank memperoleh keuntungan akan semakin rendah. Hasil penelitian ini konsisten dengan penellitian yang dilakukan oleh Ambarawati dan Abundanti (2018), Puspitasari (2014), serta Choerudin et al. (2016) yang menyimpulkan bahwa NPL berpengaruh signifikan terhadap ROA.

\section{Hasil Uji Pengaruh LDR (X2) terhadap ROA (Y2)}

Berdasarkan Tabel 6, nilai dari p-values variabel LDR (X2) menunjukkan nilai lebih besar dari 0,05 yaitu 0,295. Hasil tersebut menunjukkan bahwa LDR tidak berpengaruh signifikan terhadap ROA. Selanjutnya, nilai uji t sebesar 1,048 menunjukkan nilai yang lebih kecil dari 1,96 (nilai t-tabel) yang juga memperkuat indikasi bahwa LDR tidak berpengaruh signifikan terhadap ROA. Kedua hasil tersebut menunjukkan bahwa H4 ditolak. Perolehan hasil ini mengambarkan bahwa rasio LDR yang dimiliki bank BUMN selama periode penelitian berada pada standar yang ditetapkan oleh Bank Indonesia (80\%-110\%). Kondisi tersebut mengakibatkan LDR bank-bank BUMN yang dianalisis tidak berpengaruh signifikan terhadap ROA. Nilai LDR yang tidak terlalu tinggi atau pun tidak terlalu rendah 
tidak akan memberikan dampak pada perubahan laba. Hasil penelitian ini sejalan dengan penelitian yang dilakukan oleh Nugrahaning \& Wahyudi (2016). Namun, hasil ini berbanding terbalik dengan penelitian Ambarawati dan Abundanti (2018) dan Kunarsih et al. (2018) yang menyimpulkan bahwa LDR berpengaruh signifikan terhadap ROA.

\section{Hasil Uji Pengaruh NIM (Y1) terhadap ROA (Y2)}

Berdasarkan Tabel 6, nilai p-values variabel NIM (Y1) menunjukkan nilai lebih kecil dari 0,05 yaitu 0,000. Hasil tersebut dapat diartikan bahwa NIM memiliki pengaruh signifikan terhadap ROA. Nilai uji t sebesar 6,269 lebih besar dari 1,96 (nilai t-tabel). Uji t tersebut menunjukkan bahwa NIM berpengaruh signifikan terhadap ROA, sehingga H5 diterima. Hasil ini dikarenakan NIM merupakan rasio yang digunakan untuk mengukur kemampuan manajemen bank mengelola aktiva produktifnya untuk menghasilkan pendapatan bunga bersih (Pandia, 2012). Semakin besar peningkatan NIM yang diperoleh bank, maka hal itu akan berpengaruh pada peningkatan laba atau ROA bank tersebut. Hasil ini konsisten dengan penelitian oleh Zulhelmi dan Utomo (2017), Kunarsih et al. (2018), Kassem dan Sakr (2018), Purwoko \& Sudiyanto (2013), Dewi, Herawati, dan Sulindawati (2015), serta Bilal et al. (2013) yang menyimpulkan bahwa NIM berpengaruh signifikan terhadap ROA.

\section{Hasil Uji Pengaruh NPL (X1) terhadap ROA (Y2) melalui NIM (Y1)}

Berdasarkan Tabel 7, nilai p-values variabel NPL (X1) menunjukkan nilai lebih besar dari 0,05 yaitu 0,666 yang dapat diartikan bahwa NPL tidak berpengaruh signifikan terhadap ROA melalui mediasi NIM, sedangkan nilai uji t sebesar 0,432 juga menunjukkan lebih besar dari 1,96 (nilai t-tabel) yang berarti NPL tidak berpengaruh signifikan terhadap ROA melalui mediasi NIM, sehingga H6 ditolak. Hasil ini mengindikasikan besarnya pendapatan bunga bank tidak mampu memediasi pengaruh kemampuan bank dalam menyanggah kegagalan kredit bermasalah terhadap laba atau ROA bank. Apabila tingkat kredit bermasalah yang dimiliki bank terlalu tinggi, maka kondisi tersebut akan menurunkan kemungkinan bank memperoleh profit atau laba. Hasil ini konsisten dengan penelitian yang dilakukan oleh Anindiansyah, Sudiyatno, Puspitasari, dan Susilowati (2020) serta Apriani dan Mansoni (2019) yang menyimpulkan bahwa NPL tidak berpengaruh signifikan terhadap ROA melalui NIM.

Tabel 7. Uji Hipotesis Pengaruh Tidak Langsung

\begin{tabular}{lccccc}
\hline & $\begin{array}{c}\text { Original } \\
\text { Sample }(\mathrm{O})\end{array}$ & $\begin{array}{c}\text { Sample } \\
\text { Mean }(\mathbf{M})\end{array}$ & $\begin{array}{c}\text { Standard Deviation } \\
(\text { STDEV) }\end{array}$ & $\begin{array}{c}\text { t-statistics } \\
([\mathrm{O} / \mathrm{STDEV}])\end{array}$ & p-values \\
\hline $\mathrm{X} 1 \rightarrow \mathrm{Y} 1$ & & & & & \\
$\mathrm{X} 1 \rightarrow \mathrm{Y} 2$ & $-0,063$ & $-0,055$ & 0,145 & 0,432 & 0,666 \\
$\mathrm{X} 2 \rightarrow \mathrm{Y} 1$ & & & & 2,359 & 0,019 \\
\hline $\mathrm{X} 2 \rightarrow \mathrm{Y} 2$ & $-0,398$ & $-0,394$ & 0,169 & & \\
\hline $\mathrm{Y} 1 \rightarrow \mathrm{Y} 2$ & & & & \\
\hline
\end{tabular}

Sumber: Data sekunder diolah (2021). 


\section{Hasil Uji Pengaruh LDR (X2) terhadap ROA (Y2) melalui NIM (Y1)}

Berdasarkan Tabel 7, nilai p-values variabel LDR (X2) menunjukkan nilai yang lebih kecil dari 0,05 yaitu 0,019. Hasil tersebut menunjukkan bahwa LDR memiliki pengaruh signifikan terhadap ROA melalui mediasi NIM. Hasil uji t sebesar 2,359 juga menunjukkan nilai lebih besar dari 1,96 (nilai t-tabel) yang dapat diartikan pula bahwa LDR berpengaruh signifikan terhadap ROA melalui mediasi NIM, sehingga H7 diterima. Hasil ini mengindikasikan bahwa likuiditas bank yang baik mampu meningkatkan ROA apabila pendapatan bunga bank (NIM) besar. Hasil ini konsisten dengan penelitian Anindiansyah et al. (2020), Hardiyanti dan Febriatmoko (2016), serta Vodova (2012) yang menyimpulkan bahwa LDR berpengaruh signifikan terhadap ROA melalui NIM.

\section{KESIMPULAN DAN SARAN}

Berdasarkan uraian hasil penelitian dan pembahasan, maka hasil penelitian ini menemukan bahwa NPL tidak berpengaruh signifikan terhadap NIM. Namun, NPL dapat berpengaruh langsung secara signifikan terhadap ROA dan tidak berpengaruh signifikan terhadap ROA melalui mediasi NIM. Selanjutnya, LDR berpengaruh signifikan terhadap NIM, tetapi LDR tidak berpengaruh signifikan terhadap ROA. Selain itu, LDR dapat berpengaruh signifikan terhadap ROA melalui mediasi NIM. Di sisi lain, NIM berpengaruh signifikan terhadap ROA.

Dari hasil penelitian ini, bank-bank khususnya bank BUMN yang dianalisis direkomendasikan untuk memperhatikan kinerjanya, terutama yang berkaitan dengan kredit bermasalah (NPL). Dengan mengambil kebijakan atau keputusan yang tepat untuk meningkatkan kinerja, bank dapat menerapkan manajemen resiko guna mengatasi terjadinya peningkatan angka NPL, khususnya dalam penyaluran kredit. Bank harus benar-benar melakukan pengecekan terhadap calon nasabah sebelum kredit dicairkan. Selanjutnya, bank dapat melihat secara langsung kondisi di lapangan dalam penggunaan kredit, serta jeli dalam memperhatikan cash flow yang diperoleh dari kredit yang disalurkan, sehingga bank mampu mengantisipasi terjadinya hal yang tidak diinginkan, seperti kredit kurang lancar, diragukan, dan kredit macet agar bank mampu memaksimalkan laba yang diperoleh.

Penelitian selanjutnya disarankan untuk menggunakan variabel-variabel lain yang dapat mempengaruhi perolehan ROA. Penelitian mendatang dapat menggunakan metode atau teknik analisis lain guna memperdalam analisis, serta membandingkannya dengan metode yang telah digunakan pada penelitian ini. Melalui variasi teknik analisis dapat diketahui model mana yang memberikan hasil terbaik. Selain itu, penelitian mendatang juga diharapkan dapat memperpanjang periode penelitian agar memperoleh hasil yang lebih baik dan akurat.

\section{DAFTAR REFERENSI}

Alamsyah, L. (2018). Pengaruh LDR, IPR, APB, NPL, BOPO, PR, dan FACR terhadap ROA pada Bank Swasta Nasional Go Public. Jurnal Keuangan dan Perbankan, 4, 140 . 
Ambarawati, I. G. A. D., \& Abundanti, N. (2018). Pengaruh Capital Adequacy Ratio, Non Performing Loan, Loan to Deposit Ratio terhadap Return on Asset. E-Jurnal Manajemen Universitas Udayana, 7(5), 2410-2441.

Aminah, F. N., Suharsono, A., \& Ahmad, I. S. (2016). Pengaruh Rasio Keuangan terhadap Nilai Perusahaan pada Sektor Perbankan yang Tercatat di Bursa Efek Indonesia Menggunakan Metode Structural Equation Modelling-Partial Least Square. Jurnal Sains dan Seni ITS, 5(2), 402-407.

Andrianto, A., Fatihuddin, D., \& Firmansyah, A. (2019). Manajemen Bank. Surabaya: CV Penerbit Qiara Media.

Anindiansyah, G., Sudiyatno, B., Puspitasari, E., \& Susilowati, Y. (2020). Pengaruh CAR, NPL, BOPO, dan LDR terhadap ROA dengan NIM sebagai Variabel Intevening (Studi pada Bank yang Go Publik di Bursa Efek Indonesia Periode Tahun 20152018). Proceeding SENDI_U (Seminar Nasional Multi Disiplin Ilmu dan Call of Papers, Universitas Stikubank (Unisbank), 22 Juli, 560-567.

Apriani, S. D., \& Mansoni, L. (2019). Pengaruh CAR, LDR Dan NPL terhadap Profitabilitas pada Bank yang Terdaftar di Bursa Efek Indonesia (BEI)(Studi Kasus PT. Bank Bukopin TBK Tahun 2005-2018). Jurnal Ekonomi Manajemen Perbankan, 1(2), 86-94.

Ascarya, A., \& Yumanita, D. (2010). Determinants of Bank's Net Interest Margin in Indonesia. International Conference on Eurasian Economies 2010, Istanbul, Session 4A Finance, 252-257.

Astohar, A., Rahmadhani, S., \& Nurlita, D. (2019). Faktor yang Berpengaruh terhadap Profitabilitas dengan Net Interest Margin sebagai Variabel Intervening pada Bank Perkreditan Rakyat di Indonesia. Among Makarti, 12(2), 70-89. http://dx.doi.org/10.52353/ama.v12i2.184.

Bank BNI (2019). Laporan Tahunan Bank Negara Indonesia (BNI). Diakses tanggal 30 Desember 2020 di https://www.bni.co.id/id$\mathrm{id} /$ perusahaan/hubunganinvestor/laporanpresentasi.

Bank BRI (2019). Laporan Tahunan Bank Rakyat Indonesia (BRI). Diakses tanggal 30 Desember 2020 di https://bri.co.id/report.

Bank BTN (2019). Laporan Tahunan Bank Tabungan Negara. Diakses tanggal 30 Desember 2020 di https://www.btn.co.id/-/media/UserDefined/Document/Hubungan-Investor/ind/LaporanTahunan/Laporan_Report_BTN_2019_v2.pdf.

Bank Mandiri (2019). Laporan Tahunan Bank Mandiri. Diakses tanggal 30 Desember 2020 di https://bankmandiri.co.id/web/ir/annual-reports.

Bilal, M., Saeed, A., Gull, A. A., \& Akram, T. (2013). Influence of Bank Specific and Macroeconomic Factors on Profitability of Commercial Bank: A Case Study of Pakistan. Research Journal of Finance and Accounting. 4(2), 117-126.

BPK (2015). Peraturan Bank Indonesia Nomor: 17/11/PBI/2015 tentang Perubahan Atas Peraturan Bank Indonesia Nomor: 15/15/PBI/2013 tentang Giro Wajib Minimum Bank Umum dalam Rupiah dan Valuta Asing bagi Bank Umum Konvensional. 
Diakses pada tanggal 20 Maret 2021 di

https://peraturan.bpk.go.id/Home/Details/135541/peraturan-bi-no-1721pbi2015tahun-2015.

BPK (2004). Peraturan Bank Indonesia nomor 6/10/PBI/2004 tentang Sistem Penilaian Tingkat Kesehatan Bank Umum. Diakses pada tanggal 13 Januari 2021 di https://peraturan.bpk.go.id/Home/Details/137709/peraturan-bi-no-610pbi2004.

Choerudin, A., Yuniatun, E., \& Kusdiasmo, B. (2016). Pengaruh Non Performing Loan (NPL) dan Loan to Deposit Ratio (LDR) terhadap Return on Asset (ROA) dengan Capital Adequacy Ratio (CAR) sebagai Variabel Intervening (Studi pada Bank Umum yang Terdaftar di BEI Periode Tahun 2012-2015). ProBank: Jurnal Ekonomi dan Perbankan, 2(2), 28-47.

Dewi, L. E., Herawati, N. T., \& Sulindawati, L. G. E. (2015). Analisis Pengaruh NIM, BOPO, LDR, dan NPL terhadap Profitabilitas (Studi Kasus pada Bank Umum Swasta Nasional yang Terdaftar pada Bursa Efek Indonesia Periode 2009-2013). JIMAT (Jurnal Ilmiah Mahasiswa Akuntansi) Undiksha, 3(1), 1-11.

Ghozali, I. (2006). Structural Equation Modeling; Metode Alternatif dengan PLS. Semarang: BP Universitas Diponegoro.

Ghozali, I., \& Latan, H. (2015). Partial Least Square Konsep, Teknik dan Aplikasi Menggunakan Program SmartPLS 3.0 untuk Penelitian Empiris. Semarang: BP Universitas Diponegoro.

Hardiyanti, W., \& Febriatmoko, B. (2016). Pengaruh LDR, dan BOPO terhadap ROA dengan NIM sebagai Variabel Intervening Studi pada Bank Umum di Indonesia Periode Tahun 2011-2013. Dinamika Akuntansi Keuangan dan Perbankan, 5(2), 155-166.

Hussein, A. S. (2015). Penelitian Bisnis dan Manajemen Menggunakan Partial Least Squares (PLS) dengan SmartPLS 3.0. Modul Ajar. Malang: FEB Universitas Brawijaya.

Julaeha, L. (2015). Pengaruh Non Performing Loan, Net Interest Margin, Biaya Operaional/Pendapatan Operasional dan Loan to Deposit Ratio terhadap Profitabilitas Bank (Studi Kasus Bank Rakyat Indonesia, Tbk. Periode 2003-2014). Jurnal Ekonomi Bisnis, 20(3), 202-206.

Kasmir, D. (2012). Manajemen Perbankan. Edisi Revisi. Jakarta: PT RajaGrafindo Persada.

Kassem, N. M., \& Sakr, A. (2018). The Impact of Bank-Specific Characteristics on the Profitability of Commercial Banks in Egypt. Journal of Finance and Bank Management, 6(2), 76-90. http://dx.doi.org/10.15640/jfbm.v6n2a8.

Kunarsih, K., Andini, R., \& Suprijanto, A. (2018). Pengaruh NIM, NPL dan LDR terhadap Kinerja Keungan (ROA) dengan CAR sebagai Variabel Intervening (Studi Kasus Bank BUMN yang Terdaftar di BEI Periode Tahun 2012-2016). Jurnal Ilmiah Mahasiswa S1 Akuntansi Universitas Pandanaran, 4(4), 1-19. 
Lalujan, D. N., Pelleng, F. A., \& Tumbel, T. (2016). Analysis of Bank Indonesia Rate of Return on Asset at the PT Bank Mandiri, Tbk. Manado. Jurnal Administrasi Bisnis (JAB), 4(3), 1-12.

Manurung, A. H., \& Dezmercoledi, A. (2013). Net Interest Margin: Bank Publik di Indonesia. Journal of Business and Entrepreneurship, 1(1), 64-79.

Margaret, R.M.P., \& Nurmayanti. 2014. Faktor-Faktor yang Mempengaruhi Net Interest Margin (Bank Go Public Tahun 2008-2011). Jurnal Tepak Manajemen Bisnis, 6(3), 69-80.

Million, G., Matewos, K., \& Sujata, S. (2015). The Impact of Credit Risk on Profitability Performance of Commercial Banks in Ethiopia. African Journal of Business Management, 9, 59-66.

Nugrahaning, S., \& Wahyudi, S. (2016). Analisis Pengaruh NPL dan LDR terhadap NIM dengan ROA sebagai Intervening, Pengaruh NPL terhadap NIM dengan CAR dan ROA sebagai Intervening, serta BOPO terhadap NIM Bank Go Public di Indonesia Periode 2011-2015. Diponegoro Journal of Management, 5(4), 76-84.

Pandia, F. (2012). Manajemen Dana dan Kesehatan Bank. Jakarta: Rineka Cipta.

Parathon, A. A. (2013). Analisis Rasio Keuangan Perbankan sebagai Alat Ukur Kinerja Keuangan Bank (Studi Kasus PT. Bank Pembangunan Daerah Jawa Timur, Tbk. Surabaya Periode 2009-2012). Jurnal Administrasi Bisnis, 3(2), 1-12.

Otoritas Jasa Keuangan (2011a). Peraturan Bank Indonesia Nomor: 13/1/PBI/2011 tentang Penilaian Tingkat Kesehatan Bank Umum. Diakses tanggal 15 Januari 2021pada https://www.ojk.go.id/id/kanal/perbankan/regulasi/peraturan-bankindonesia/Pages/peraturan-bank-indonesia-nomor-13-1-pbi-2011.aspx.

Otoritas Jasa Keuangan (2011b). Surat Edaran nomor 13/24/DPNP tertanggal 25 Oktober 2011. Surat Edaran kepada Semua Bank Umum Konvensional di Indonesia. Diakses pada tanggal 13 Januari 2021 di https:/www.ojk.go.id/Files/regulasi/perbankan/sebi/2011/se_132311.pdf.

Purwoko, D., \& Sudiyanto, B. (2013). Faktor-faktor yang Mempengaruhi Kinerja Bank (Studi Empirik pada Industri Perbankan di Bursa Efek Indonesia). Jurnal Bisnis dan Ekonomi, 20(1), 25-39.

Puspitasari, E. (2014). Analisis Faktor-Faktor yang Mempengaruhi Net Interest Margin pada Bank-bank Umum di Indonesia. Jurnal Ilmu Manajemen, 2(4), 1-13.

Putri, N. K. A. P., Wiagustini, L. P., \& Abundanti, N. N. (2018). Pengaruh NPL, CAR, dan BOPO terhadap Profitabilitas pada BPR di Kota Denpasar. E-Jurnal Manajemen Universitas Udayana, 7(11), 6212-6238.

Raharjo, P. G., Hakim, D. B., Manurung, A. H., \& Maulana, T. N. A. (2014). The Determinant of Commercial Banks' Interest Margin in Indonesia: An Analysis of Fixed Effect Panel Regression. International Journal of Economics and Financial Issues, 4(2), 295-308.

Riduwan, E. A. K., \& Kuncoro, A. (2012). Cara Menggunakan dan Memaknai Path Analysis (Analisis Jalur). Bandung: Alfabeta. 
Rokhim, R. \& Wulandary. N. (2013). Pengaruh Simpanan, CAR, dan NPL pada Tingkat Deposit, Risiko Modal Hazard, dan NIM. Ekuitas: Jurnal Ekonomi dan Keuangan, 17(4), 468-485. https://doi.org/10.24034/j25485024.y2013.v17.i4.115.

Rusnaini, S., Hamirul, H., \& Ariyanto M., A. M. (2019). Non Performing Loan (NPL) dan Return on Asset (ROA) di Koperasi Nusantara Muara Bungo. Jurnal Ilmiah Manajemen, Ekonomi, \& Akuntansi, 3(1), 1-18. https://doi.org/10.31955/mea.vol3.iss1.pp1-18.

Sapti, M. (2010). Kemampuan Koneksi Matematis (Tinjauan terhadap Pendekatan Pembelajaran Savi). Limit-Pendidikan Matematika, 53(9), 60-69.

Septiani, R., \& Lestari, P. V. (2016). Pengaruh NPL dan LDR terhadap Profitabilitas dengan CAR sebagai Variabel Mediasi pada PT BPR Pasarraya Kuta. E-Jurnal Manajemen Unud, 5(1), 293-324.

Siyoto, S., \& Sodik, M. A. (2015). Dasar Metodologi Penelitian. Yogyakarta: Literasi Media Publishing.

Soetjiati, S., \& Mais, R. (2019). Analisis Faktor-Faktor yang Mempengaruhi Profitabilitas Bank Umum di Indonesia. Jurnal Akuntansi dan Manajemen, 16(01), 96-126. https://doi.org/10.36406/jam.v16i01.270.

Suciaty, A., Haming, M., \& Nur, A. (2019). Pengaruh CAR, BOPO, NPL dan LDR terhadap ROA pada Bank BUMN yang Terdaftar di Bursa Efek Indonesia. CESJ: Center of Economic Students Journal, 2(3), 57-74.

Sudarmawanti, E., \& Pramono, J. (2017). Pengaruh CAR, NPL, BOPO, NIM dan LDR terhadap ROA (Studi Kasus pada Bank Perkreditan Rakyat di Salatiga yang Terdaftar di Otoritas Jasa Keuangan Tahun 2011-2015). Among Makarti, 10(1), 1-18. http://dx.doi.org/10.52353/ama.v10i1.143.

Syarif, S. (2006). Analisis Pengaruh Rasio-rasio CAMELS terhadap Net Interest Margin. Tesis. Program Studi Magister Manajemen Universitas Diponegoro. http://eprints.undip.ac.id/15945/1/Syahru_Syarif.pdf.

Vodova. P. (2013). Determinants of Commercial Bank Liquidity in Hungary. E-Finanse: Finansowy Kwartalnik Internetowy, 9(4), 64-71.

Wibisono, M. Y., \& Wahyuni, S. (2017). Pengaruh CAR, NPF, BOPO, FDR, terhadap ROA yang Dimediasi oleh NOM. Jurnal Bisnis dan Manajemen (Journal of Business and Managemet), 17(1), 41-62. https://doi.org/10.20961/jbm.v17i1.12304.

Wulandari, N. S. D., \& Purbawangsa, I. B. A. (2019). Pengaruh NPL dan LDR terhadap Profitabilitas dengan CAR sebagai Variabel Mediasi pada LPD Kota Denpasar. EJural Manajemen, 8(4), 2098-2124.

Zulhelmi, Z., \& Utomo, R. B. (2017). Pengaruh CAR, BOPO, NIM, NPL, dan LDR terhadap Profitabilitas Perbankan Umum Milik Pemerintah di Indonesia pada Tahun 2011-2013. Bilancia: Jurnal Ilmiah Akuntansi, 1(1), 95-109. 